Archived version from NCDOCKS Institutional Repository http://libres.uncg.edu/ir/asu/

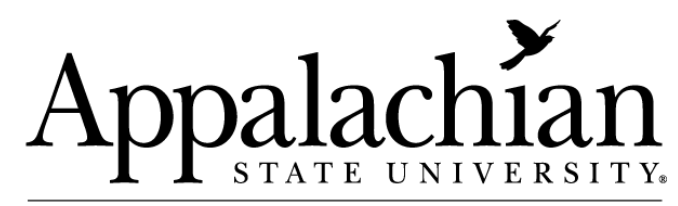

$\overline{B \text { O O N E, N O R T H C A R L I N A }}$

\title{
Science As A Classed And Gendered Endeavor: Persistence Of Two White Female First-Generation College Students Within An Undergraduate Science Context
}

\author{
By: Rachel E. Wilson and Julie Kittleson
}

\begin{abstract}
As colleges and universities aim for greater diversity in their undergraduate populations, one population researchers consider is first-generation students, or students whose parents do not have a college education. The research reported here addresses first-generation college students' discipline of study (e.g., biology) and its impact on their persistence. Exploring how female, low-income, first-generation college students evaluate their persistence within undergraduate science learning environments contributes to understanding how gender and social class influence persistence in STEM fields. Two White, female, low-income, first-generation college students were interviewed during their last year in college. Using constant comparative coding methods and Ricoeur's (Ricoeur [1984] Time and narrative, Volume I (K. McLaughlin \& D. Pellauer, Trans.). Chicago, IL: The University of Chicago Press) description of narrative construction, common tensions were identified related to participants' descriptions of undergraduate science as competitive. These persistence-related tensions are (1) differing experiences in lecture and lab, (2) managing time to work, study, and maintain family relationships, and (3) weighing their personal (family) priorities against the longer time it would take them to reach their science-related career goals. These tensions depict a traditional undergraduate science learning environment focused on individuals and abstract knowledge that positions female lower-income students as "academic non-competitors" because of the importance of kinship ties and physical skills in their cultural background (Lareau [2002] American Sociological Review 67(5), 747-776; Lareau [2003] Unequal childhoods: Class, race, and family life. Berkeley: University of California Press). The participants' experiences support that the gendered and classed expectations needed to succeed in a science environment could be somewhat alleviated through reforms to traditional lecture and laboratory undergraduate science courses that promote cooperative student learning groups and integration of lecture with hands-on activities.
\end{abstract}

Wilson, R.E. and Kittleson, J. (2013), Science as a classed and gendered endeavor: Persistence of two white female first-generation college students within an undergraduate science context. J Res Sci Teach, 50: 802-825. https://doi.org/10.1002/tea.21087. Publisher version of record available at: https://onlinelibrary.wiley.com/ doi/10.1002/tea.21087 


\title{
Science as a Classed and Gendered Endeavor: Persistence of Two White Female First-Generation College Students Within an Undergraduate Science Context
}

\author{
Rachel E. Wilson ${ }^{1}$ and Julie Kittleson ${ }^{2}$ \\ ${ }^{1}$ Appalachian State University, Curriculum and Instruction, Reich College of Education, \\ ASU Box 32047, Boone, North Carolina, 28608-2047 \\ ${ }^{2}$ University of Georgia, Mathematics \& Science Education, Athens, Georgia
}

\begin{abstract}
As colleges and universities aim for greater diversity in their undergraduate populations, one population researchers consider is first-generation students, or students whose parents do not have a college education. The research reported here addresses first-generation college students' discipline of study (e.g., biology) and its impact on their persistence. Exploring how female, low-income, first-generation college students evaluate their persistence within undergraduate science learning environments contributes to understanding how gender and social class influence persistence in STEM fields. Two White, female, lowincome, first-generation college students were interviewed during their last year in college. Using constant comparative coding methods and Ricoeur's (Ricoeur [1984] Time and narrative, Volume I (K. McLaughlin \& D. Pellauer, Trans.). Chicago, IL: The University of Chicago Press) description of narrative construction, common tensions were identified related to participants' descriptions of undergraduate science as competitive. These persistence-related tensions are (1) differing experiences in lecture and lab, (2) managing time to work, study, and maintain family relationships, and (3) weighing their personal (family) priorities against the longer time it would take them to reach their science-related career goals. These tensions depict a traditional undergraduate science learning environment focused on individuals and abstract knowledge that positions female lower-income students as "academic non-competitors" because of the importance of kinship ties and physical skills in their cultural background (Lareau [2002] American Sociological Review 67(5), 747-776; Lareau [2003] Unequal childhoods: Class, race, and family life. Berkeley: University of California Press). The participants' experiences support that the gendered and classed expectations needed to succeed in a science environment could be somewhat alleviated through reforms to traditional lecture and laboratory undergraduate science courses that promote cooperative student learning groups and integration of lecture with hands-on activities. (c) 2013 Wiley Periodicals, Inc. J Res Sci Teach 50: 802-825, 2013
\end{abstract}

Keywords: first-generation students; general science; diversity; socio-cultural issues; college science teaching

As colleges and universities aim for greater diversity in their undergraduate populations, there has been a push to attract students from a variety of socioeconomic backgrounds (Schmidt, 2010). One such population is students whose parents do not have a college education, or first-generation students (Billson \& Terry, 1982). The persistence of first-generation students in higher education, however, has been a concern because after controlling for factors that affect the persistence of any

Correspondence to: Rachel E. Wilson; E-mail: wilsonre3@appstate.edu 
student in college - such as less adequate high school preparation, a first-year GPA in the bottom $25 \%$ of the class, taking only a part-time course load, working full-time, and being marriedfirst-generation students are still more likely to drop out of college than their peers with collegegraduate parents (Choy, 2001). In addition, first-generation students are more likely to experience "intersecting sites of oppressions based on race, class, and gender," (Lohfink \& Paulsen, 2005, p. 418) as they are more likely to identify as part of a minority ethnicity, have families in the lowest income quartile, and/or be female (Nuñez \& Cuccaro-Alamin, 1998). Given that first-generation college students are more likely to match certain demographics of underrepresented students in science (due to gender and/or race/ethnicity) (NSF, 2011), more attention should be given to the persistence of first-generation college students studying science (Packard \& Babineau, 2009).

Very little research on the experiences of first-generation college students has focused on their persistence within particular disciplines of study. Research on the experiences of first-generation college students in community colleges (London, 1992; Weis, 1992) and their experiences after transferring from community colleges (Packard, Gagnon, LaBelle, Jeffers, \& Lynn, 2011) has shown the importance of focusing on students' interpretations of the undergraduate learning context. Studies on the experiences of first-generation students have also shown the varying salience of gender, race/ethnicity, and/or class as factors of influence (Orbe, 2004; Weis, 1992). In addition, we know that the persistence of underrepresented students in science is influenced by students' interpretations of undergraduate science learning contexts (Johnson, 2007; Seymour, 1995), and that their experiences of science classroom culture are influenced by the gender and/or race/ethnicity of students (Carlone \& Johnson, 2007; Johnson, Brown, Carlone, \& Cuevas, 2011). Yet, we do not know how first-generation college students studying science interpret their experiences of undergraduate science learning contexts as they approach graduation or how their gender, race/ethnicity, and/or class influence their interpretations of their experiences.

Though females as a group are making gains in their participation in science, the continued gender gap in post-undergraduate science contexts requires a deeper look at issues that may be influencing particular groups of women (NSF, 2011). While the experiences of non-White, female undergraduate students have been explored to address issues of historic underrepresentation in science (e.g., Johnson, 2007, Johnson et al., 2011; Ong, 2005), lower-class White women have not been a focused population of study. Therefore, the purpose of this article is to explore the experiences described by White, female first-generation college students from lower-income backgrounds of their undergraduate science learning context to understand how gender and social class influence their interpretations of their persistence towards their science-related career goals. We address the following research questions:

(1) How do White, low-income, female, first-generation university undergraduate students describe their undergraduate science learning environment as they evaluate their persistence within it?

(2) What tensions related to studying science do White, low-income, female, firstgeneration university undergraduate students describe as they evaluate their persistence?

\section{Relevant Literature}

\section{Undergraduate Science Learning Environments}

Higher education policy makers have discussed using first-generation status as a proxy for class (Schmidt, 2010) because first-generation students are more likely to have families in the lowest income quartile (Choy, 2001). Becky Wai-Ling Packard's work with female, 
first-generation community college students has contributed to the gap in knowledge about students' science experiences. Packard et al. (2011) studied female first-generation students' retention of STEM career intentions during the transfer process from community college to 4-year colleges. Though most of the students, after one semester, were still enrolled at the 4-year college to which they transferred, all of their participants mentioned increased difficulties at 4-year colleges. Packard et al.'s (2011) results support earlier findings that flexible work schedules and family support are significant positive factors in the persistence of first-generation community college students, while limited finances are a significant negative factor (Packard \& Babineau, 2009). In addition, Packard et al.'s (2011) findings support the conclusions of the National Science Board (2003) that the persistence of low-income students within STEM undergraduate programs is made more difficult due to structural aspects of these programs: "curricula built on pre-requisites, limited course offerings," "necessity of lab work", and "sequential acquisition of knowledge and skills along directed paths" (p. 19).

Packard et al.'s (2011) work with female first-generation transfer students also supports research on the powerful influence of the culture of undergraduate science learning environments on female students' feelings of persistence towards STEM career goals (Carlone \& Johnson, 2007; Seymour, 1995). Packard et al.'s (2011) participants described science learning environments on 4-year college campuses as unwelcoming and competitive, which supports descriptions of experiences of undergraduate science programs as a "masculine" rite of passage (Seymour, 1995) with stressful introductory "gatekeeper" courses (Hurtado et al., 2011). In such a context, Erwin and Maurutto (1998) argued that female students' ideas of themselves as exceptions to stereotypes-because they are females in science-contributed to their leaving being seen as a result of a personal failure. How authority figures and peers perceive students has been shown to be strongly influential to maintaining a science identity and persisting in the field (Calabrese Barton et al., 2013; Carlone \& Johnson, 2007; Ong, 2005). Therefore, factors related to undergraduate science programs, such as interactions with faculty and peers, have been connected to female students' interpretations of and persistence in science learning environments.

Key socio-cultural studies of students in the undergraduate math/science pipeline support the need to explore how factors in addition to gender, such as race/ethnicity and class, strongly influence the persistence of female students (Hanson, 1996; Hurtado et al., 2007). Hanson (1996) found that females who had more access to science were more likely to have a positive attitude toward and achievement in science, yet the socioeconomic background of students weakened this correlation. In testing a sociological model of persistence in college for various racial groups of science students, Hurtado et al. (2007) found that for students of all races/ethnicities, both "academic adjustment and sense of belonging" were strongly influenced by academic/intellectual development, competence and performance (p. 881). These studies support qualitative research indicating that underrepresented students' experiences are influenced by perceptions of competence and belonging (Carlone \& Johnson, 2007; Johnson et al., 2011). Few qualitative studies in science education, however, have focused on the influence of social class on students' perceptions (Richardson Bruna \& Vann, 2007).

In addition to personal interactions within the undergraduate science learning environment, cultural narratives, or messages, about science have been shown to influence students' experiences. At a large research university where the learning environment was seen as competitive, where class sizes were large, and where students had limited contact with professors, racial minority female science students responded negatively to the following two cultural values: "a narrow focus on decontextualized science and the construction of science as a gender-, ethnicity-, and race-neutral meritocracy" (Johnson, 2007, p. 810). Because science was portrayed as objective and gender- and race-neutral, these young women were not comfortable talking about 
the influence of their race and ethnicities in their science experiences, but seemed more able to identify how they were being positioned as outsiders in science.

These insights into how female students' experiences are shaped due to their gender and race/ ethnicity in personal interactions and through cultural narratives support the idea that the culture of undergraduate science learning environments could be just as influential to the persistence of female students due to their gender and social class. In the little research done on first-generation college students as science majors (Packard \& Babineau, 2009; Packard et al., 2011), how gender and social class influence the experiences of students within the culture of undergraduate learning environments and how students interpret their experiences in science has not been explored.

\section{Science and Gender}

Gender is the cultural construction of differences based on biological sex, or what Lorber (1994) calls "a social phenomenon" (p. ix). Gender is a pervasive, taken-for-granted division that can shape identities, interactions with others, and norms within institutions (Lorber, 2011; Risman, 1998, 2004). While the number of female students earning bachelor's degrees in science programs has become more equal (55.5\%), and in disciplines like the biological and pre-medical sciences are above equal (59.8\%), female representation is as few as $41.3 \%$ in physical science and $18.5 \%$ in engineering (NSF, 2011). As a result, issues of gender and equity in science continue to be a concern for researchers at the undergraduate level (Fox, Sonnert, \& Nikiforova, 2011) and at the professional level (Ecklund, Lincoln, \& Tansey, 2012; Rhoton, 2012). The continued underrepresentation of women in particular science spaces provides evidence for scholars who argue that science is a gendered field of study (Harding, 2008; Longino, 1990).

Some programs aimed at bettering the undergraduate science experience for women have not been successful in reforming institutional practices to be more gender-inclusive (Fox et al., 2011). Despite recognizing structural problems affecting the participation of female undergraduates in science and engineering programs - the most commonly identified factor being "classroom climate"-university administrators have tended to focus on individually based solutions (Fox et al., 2011). The focus on the individual by undergraduate programs through solutions such as career seminars and peer mentoring tend not to include science faculty, and as a result, do not address the identified problem of classroom culture.

While the academic science culture continues to varyingly influence the undergraduate experiences of female students (Johnson, 2007; Packard et al., 2011), it also affects the professional experiences of female scientists in the academy (Rhoton, 2012), and may shed light on the persistently low number of female scientists compared to male scientists (NSF, 2011). Gender scholars, such as Bem (1993), have argued that because males have long held the political power in society, many institutions have been created by males and from the male perspective. An androcentric point of view treats male experience as normative while "females and female experience are treated as a sex-specific deviation from that allegedly universal standard" (Bem, 1993, p. 41). For example, institutions, such as universities, were established when fulltime male workers had full-time female help at home, which can have implications for female scientists in academia and outside (Eisenhart \& Finkel, 1998), and potentially for female science students. Eisenhart and Finkel (1998) have argued that a discourse of gender neutrality can hide the influences of previously male dominated institutions by expecting everyone to maintain a good worker identity. However, this identity encompasses characteristics of a prototypical white male: their job comes first, their primary responsibility is their career, they should not sacrifice work responsibilities for child-care or domestic reasons, and there are expectations to work more than full-time and to travel extensively. The power of the gender-neutral discourse in science workplaces is supported by current research with female academic scientists, who acknowledged 
acts of gender discrimination, but continued to use "individualistic explanations for success that frame science as a gender-neutral meritocracy in which the most qualified inevitably succeed" (Rhoton, 2012, p. 713). Therefore, while the numbers of females in certain science spaces is more equal, the power of a gender-neutral discourse can still be affecting faculty and students' experiences.

\section{Gender, Race/Ethnicity, and Class}

Just as Bem (1993) has argued that cultural views of male superiority are reflected in institutions, cultural ideas about group superiority based on race/ethnicity and class are also infused into practices deemed "normal" in institutions. Collins (2000) has recommended examining the intersecting oppressions on the lives of people within institutions such as schools. The framework of intersectionality- "intersecting hierarchies of gender, race, economic class, sexuality, and ethnicity" (Collins, 1999, p. 263)—has been important for identifying how gender and race/ethnicity have influenced the science experiences of girls and women of color (Calabrese Barton et al., 2013; Johnson, 2007; Johnson et al., 2011; Ong, 2005). Instead of discussing the intersection of all axes of disadvantage suggested by Collins (2000), the participants in this study experience a particular intersection of disadvantage (gender and social class) that opens up possibilities for understanding how gender and social class can influence perceptions of persistence.

In this article, we use the term class as a "relational" concept (Bettie, 2003, p. 12) that refers to a person's relative position in society based on "practices of everyday living - practices that are both engaged in by, and simultaneously encircle, men, women, and children on a daily basis" (Weis, 2004, p. 4). In addition, Bettie (1995) has argued that class is another way "that identity is historically and contextually created" (p. 126). These socio-cultural definitions of class recognize the importance of looking beyond income-level to focus on how people are positioned or position themselves in society due to their identities and lifestyles.

Historically, class-based analyses have focused on White, working class men (Aronowitz, 1992; Willis, 1977), while more recent research has expanded conceptualizations of class by including voices of White, working class women (Weis, 1990, 2004) and by contrasting voices of White and Latina working class girls (Bettie, 2003). Bettie's (2003) ethnographic work with White and Latina high school girls revealed differences in the experiences of upwardly mobile lower class female students based on their race, though without discussion of their academic subject interests. The upwardly mobile White students did not experience the same "intra-ethnic tension within their community over the link between mobility and assimilation" that Latina students felt (Bettie, 2003, p. 161). Without explicit cultural identities connected to class, lower-class White students felt that their social position was a result of individual deficiencies of themselves or their parents. Thus, considering the intersection of gender, race/ ethnicity, and class expands understandings about the influences of these factors on the experiences of differently situated underrepresented students.

In our focus on the experiences of White, low-income, female first-generation students, we acknowledge whiteness as one of many "racial identities and cultures" (Hartmann, Gerteis, \& Croll, 2009, p. 403). When we use the word race, we are referring to a word describing a socially and historically constructed group of people (Harding, 1993). There is considerable debate about how much attention White Americans give to their own race and culture (Hartmann et al., 2009). The invisibility of White identity or culture can come about, as Perry (2001) argues, through naturalization - "the embedding of historically constituted cultural practices" that become "taken for granted" or "normal" - or through rationalization - "the embedding of whiteness within a Western rational epistemology and value paradigm that marginalizes or subordinates all things 
'cultural"' (p. 59). Perry (2001) studied White high school students and described how they saw their white identity as cultureless or post-cultural, thus denying "the significance of a past orientation and exalted a more individualistic and present- or future-oriented construction of the self" (p. 80). This "rationalist" and "individualistic" construction of self is consistent with the cultural messages of science in undergraduate science learning environments as described by Johnson (2007) and Seymour (1995), as well as within science workplaces as described by Eisenhart and Finkel (1998).

Because our participants are White and thus share the racial identity and culture of those in power in American society and in science, a discussion of the influence of race/ethnicity on their experiences is secondary to exploring the influence of gender and social class on their experiences. While research on the intersecting influences of gender and race/ethnicity has been important for identifying how these factors have influenced the science experiences of women of color (Johnson, 2007; Johnson et al., 2011; Ong, 2005), few research studies focus on how class shapes the experiences of students in science (Richardson Bruna \& Vann, 2007). Therefore, in our exploration of the experiences of White, low-income, female, first-generation students in science, their position as neophytes in undergraduate science is an important standpoint from which to gather insights into how undergraduate science learning environments position such students in relation to their class and gender (Holland, Lachicotte, Skinner, \& Cain, 1998).

\section{Theoretical Framework}

Female first-generation college students occupy a unique position in society due to their families' lack of educational experiences and their hopes of education as a key to social mobility. Therefore, as a theoretical lens, practice theory allows us to examine the salience of gender and class for participants in making meaning of their experiences as students and science majors. Practice theory focuses on the importance of cultural productions of meaning (Levinson \& Holland, 1996; Willis, 1977), socio-historical influences on learning (Lave \& Wenger, 1991), and how such meanings and practices position people in relation to networks of power (Eisenhart \& Finkel, 1998). In using practice theory, we sought to address the socio-cultural issues facing firstgeneration students and how they respond to these issues when pursuing science-related career goals. Recent research in science education using practice theory has addressed the effects of positioning on how people make meaning of this positioning and respond in their day-to-day practices (Calabrese Barton et al., 2013; Carlone, Haun-Frank, \& Webb, 2011; Carlone \& Johnson, 2007; Johnson, 2007).

We chose to frame this study using practice theory because by attending college, firstgeneration college students are actively seeking to change their positions in society through advanced education. Therefore, using practice theory allows us to address both structural influences on students' experiences and the possibilities for agency within such structures. Holland and Leander (2004) argue that researchers can analyze tensions between structure and agency to explore how people respond to ways in which they are positioned based on sociocultural beliefs about factors such as gender and class. For example, traits historically associated with men (whether physical or behavioral) have been culturally determined to be ideal traits for people in power, whereas traits historically associated with women have been culturally determined to be non-ideal (Bem, 1993). Therefore, when a woman feels positioned based on her gender, she is being positioned as non-ideal based on cultural narratives of gender. A woman can respond to the experience of being positioned based on cultural narratives of gender by assenting (and therefore reinforcing this cultural narrative of gender) or resisting (and therefore trying to exert agency within the structure). Acts of resistance in positioning events, however, are limited 
based on the available positions, or available narratives, for others to use in interpreting such resistance.

Practice theory allows researchers to analyze students' interpretations of their experiences and the consequences of the meaning they assign to such experiences based on their responses. This framework is important because though students may share demographic variables, their interpretations of their experiences will not necessarily be similar (Brickhouse, Lowery, \& Schultz, 2000). Carlone et al. (2011) found that science as an endeavor of individual knowledge construction limited the number of students who personally identified with science. "Normative science practices" within elementary classrooms shaped students' collective interpretations of good science student (structure) and influenced whether or not students' affiliated themselves with the notion of "science person" (agency) (Carlone et al., 2011, p. 465). In addition to "normative school science practices," socio-cultural ideas of gender and race can act as power structures to positively or negatively influence middle school girls' science identity work over time (Calabrese Barton et al., 2013, p. 32). By focusing on the dynamic between power structures and individual desires that individuals from non-dominant groups experience, researchers can explore how such individuals interpret learning environments, providing perspectives on the salience of variable influences on participants' experiences and persistence within undergraduate science.

\section{Methodology}

\section{Hermeneutics and Narratives}

As a social science research approach, hermeneutics has been used to interpret the "texts" of human interaction, that is, dialogue and behaviors (Crotty, 1998; Patton, 2002). Research that uses philosophical hermeneutics is concerned with understanding how people make meaning from their experiences in the world (Freeman, 2007). The language we use to describe something is a product of a social context, and therefore, the language we use to describe our experiences holds meanings shared in that context (Polkinghorne, 1988). Using hermeneutics as a theoretical framework in this research allows us to consider participants' meanings of their lived experience as well as the socio-cultural influences (such as cultural narratives) on those meanings.

Practice theory is consistent with the hermeneutic ideas of narrative construction as described by Ricoeur $(1984,1992)$. "By narrating a life of which I am not the author as to existence, I make myself its coauthor as to its meaning" (Ricoeur, 1992, p. 162). Ricoeur's (1984) ideas about narration as a meaning making practice take into account how both structure and agency influence the construction and telling of narratives. Ricoeur (1984) acknowledges how structure influences narratives through the dependence on cultural ideas (pre-understandings) forming the conceptual network within which individuals construct narratives, as well as the intersubjective nature of constructing narratives for, and telling narratives to, an audience.

Ultimately, narration is an interpretive process. As you construct a narrative about your experiences, you use ideas from the cultural context to make sense of your experiences as you are telling them. Therefore, the act of constructing a narrative involves the individual making meaning of experience and the agency that individuals hold in responding to and within a conceptual network (structure) (Ricoeur, 1984).

The act of positioning (Holland \& Leander, 2004) or ascription of a role (Ricoeur, 1992) becomes an opportunity for a person to assent to or resist available narratives in cultural contexts. In using hermeneutic ideas about narrative construction and interpretation, we focus on participants' descriptions of their experiences to gain insight into the dynamic between the narratives they used to explain their experiences (agency), narratives used to position them in their context (structure), and the consequences of these cultural narratives for the participants' 
interpretation of their own persistence within science. This type of research is particularly important when considering the persistence of first-generation students who are uniquely positioned within the undergraduate context and can provide valuable insight into how that context positions people within it (Holland et al., 1998). In describing their experiences, the participants refer to either cultural narratives in use in their undergraduate science learning environment, at home, or both or neither. Using hermeneutics as a foundation for data collection and analysis, therefore, provides an opportunity to focus on how the participants make meaning of their experiences and their use of cultural narratives for explaining these experiences.

\section{Research Context}

This qualitative study involved 10 female science majors who were first-generation college students at Southern University, or SU, a large, public, research-intensive university in the southeastern United States in the spring term of 2010. At the time of the study, more than 25,000 undergraduate students were enrolled at SU, approximately $56 \%$ of which were female. In addition to a College of Arts and Sciences, which contained traditional science discipline departments, SU also had a number of applied science colleges and departments. As science majors, the participants shared their major courses with up to 3,300 students, or $12.5 \%$ of the undergraduate student population.

\section{Selection and Recruitment of Participants}

Participants were selected based on the following criteria: (a) they have parents who do not have a college education, (b) they are female, and (c) they were in their second year or higher in their pursuit of an undergraduate science degree. The third criterion is noteworthy because firstgeneration students are more likely to drop out within their first year of college or between their first and second years of college (Choy, 2001). In a study about how first-generation students evaluate their persistence, it was important to interview students who have been able to persist through at least their first year in college.

In order to recruit participants, the first author sent an email to upper-level biology majors via a listserv maintained by the Biological Sciences division. The Biological Sciences division was chosen because biology tends to attract a more equal proportion of male and female students than other science disciplines (NSF, 2011). Further, the Biological Science listserv reaches students from several departments at Southern University, including Biochemistry and Molecular Biology, Plant Biology, Cellular Biology, Entomology, Genetics, Marine Sciences, Microbiology, and Ecology. Lastly, the first author visited classes in two colleges of applied sciences at Southern University and explained the purpose of the research project. After these recruitment efforts, eleven participants volunteered, with ten participants remaining active in the study until the conclusion.

\section{Bounding the Analysis}

Choosing a case for analysis, according to Merriam (1998), requires the researcher to choose a "single entity, a unit around which there are boundaries" (p. 27). Case studies in qualitative research result in knowledge that is "generalizable to theoretical propositions, not to populations" because it can expand our understanding of theory (Yin, 2009, p. 15). Statistical research has found that first-generation college students are more likely to: be female, be of a minority race/ethnicity, be from a family in the lowest income quartile, be of a non-traditional college age, be financially independent of their families, live off-campus, and/or hold an off-campus job (Choy, 2001; Nuñez \& Cuccaro-Alamin, 1998). In this article, Jamie and Judy comprise a single case for analysis because their shared characteristics fit all but one of the demographic trends listed above: they are 
White. In addition to being White, Judy and Jamie were female undergraduate students of a nontraditional age (in their mid-twenties). They both grew up in small rural towns in the southeastern US, and in addition to having parents who had not attended college, their parents did not graduate from high school. Judy and Jamie both attended public high schools and did not take advanced placement (AP) or honors courses. Both started taking college courses directly after their high school graduations, however, they took time off after their first year to work and re-enrolled within 5 years of their high school graduations.

Their shared demographics with each other and with the demographic trends in firstgeneration college student research, save for race/ethnicity, make them a unique case to examine their interpretations of the salience of gender and class on their persistence in science. The use of unique cases has been used to make more visible issues of power of dominant cultures in science education (Brandt, 2008; Calabrese Barton \& Yang, 2000). Thus, the goal in analyzing a case such as Jamie and Judy, with a focus on the interpretations of these individuals, can provide new perspectives on the intersecting influences of gender and class and their salience in the persistence of underrepresented students in science.

\section{Data Collection}

The main mode of data collection in this study was interviewing. The first author conducted three interviews with each participant throughout the spring term of 2010, using a three-interview format described by Seidman (2006). Each interview was audio-recorded, and lasted between one to two hours. In each interview participants were encouraged to describe particular events. It is understood that eliciting narratives of people's experiences helps reveal their interpretations of those experiences because as people arrange discrete events into a storyline, they link events with meanings (Polkinghorne, 1995). The first two interviews focused on participants' life and educational histories, day-to-day experiences as college students, their experiences as science majors and their interactions with faculty and other students. Not until the third interview were participants explicitly asked questions about the salience of gender and race in their experiences. Instead of asking about the salience of class in the third interview, they were asked about the salience of their first-generation status. (Interview questions are available as Supporting Information accompanying the article.)

In the third interview, participants were asked to read and respond to two vignettes constructed by the first author. (Vignettes are available as Supporting Information accompanying the article.) The use of vignettes in hermeneutic research provides the researcher an opportunity to hear their participants' interpretations of issues presented in a narrative (Freeman, 2007). Responding to the interpretations or evaluations of other people as presented in research literature provides a shared set of meanings for participants to respond to (Freeman, 2007). In reading and responding to vignettes, participants were given the opportunity to respond to someone else's experiences, if they felt uncomfortable talking about their own experiences, and in addition, to respond to what they recognize as salient among the intersecting themes of gender, race/ethnicity, and class presented in the vignettes.

In this study, instead of creating vignettes constructed using narratives selected from the current study data, the vignettes were constructed to reflect issues that other researchers (Bettie, 2003; Ong, 2005) have highlighted in studies about female students and the intersecting influences of gender, race, and class. Each vignette describes a fictional female first-generation college student who is a science major, one of which is Black and one of which is White. Having participants respond to vignettes provides a form of member-checking that is consistent with hermeneutic methodologies, in that participants are asked to give their own opinions of research themes based on their experiences and interpretations (Freeman, 2007). 


\section{Data Analysis}

Interview recordings were transcribed and then analyzed using grounded theory methods of constant comparative coding (Charmaz, 2006) and Ricoeur's (1984) descriptions of the construction of narratives. The first author scanned through each interview transcript to identify passages where participants narrated events related to persistence. Rather than extract words, phrases, or lines from the interview transcripts to fit into the different element categories in a table, which would lead to a loss in coherence of the narrative, the first author analyzed whole narrative passages in which participants described an event related to persistence.

These "persistence" narrative passages were analyzed using questions the first author developed from Ricoeur (1984) to tease apart the structural and temporal elements of their narratives from the cultural narratives they were drawing on in making meaning of their experiences. Examples of structural elements include: goals, agents, motives, circumstances, interactions, and outcomes. Examples of questions to tease out the cultural narratives are: How does the narrator evaluate people or events? What basis is the narrator using to make evaluative comments? For example, if a participant was evaluating her experience of a certain event, she might refer to the idea of school as a competition in explaining why a certain outcome occurred in relation to her goals and interactions.

This analysis stage served to identify the context and events, as well as highlight the cultural narratives that participants were using in making meaning of those events. After coding the structural, temporal, and cultural elements, the narrative excerpt would then be labeled based on the cultural narrative used by the participant in their evaluation. Narratives from all participants that were labeled with the same cultural narrative (ex. school as a competition) were then compared and analyzed across participants to identify circumstances (a structural element) the participants described in relation to the cultural narrative. The process of cross-comparative coding of structural, temporal, and cultural elements of narratives is much like what Charmaz (2006) described except that Ricoeur's (1984) identified elements of narratives were used to select sections from the transcripts for analysis. Therefore, findings were compiled from narrative passages from Judy and Jamie labeled school as a competition (cultural narrative). These school as a competition narratives were then analyzed for common structural elements from the initial coding which were used to generate the tensions described in the findings: that is, how they evaluate their persistence and the relationships between circumstances (opportunities/constraints), interactions with agents (faculty, peers, friends, family), goals, and outcomes they discussed in explaining their experiences.

In order to address subjectivities throughout the research process, we used memos to as a way to acknowledge our preconceptions of the data and "bridle" our subjectivities (Dahlberg, 2006). Our memos were our way of keeping a constant tension between our pre-understanding (assumptions) and the understandings we gleaned from the research process. This act of bridling is consistent with philosophical hermeneutics and the dynamic of maintaining dialogue between the researcher's interpretations and understandings and those of the participants.

\section{Findings}

As Judy and Jamie described their lives, they constructed narratives in which they referred to cultural narratives-school as a competition-that were available in the broader social context to explain and evaluate their experiences. This cultural narrative-school as a competitionrepresents a structural influence from their undergraduate science degree programs that positioned them in specific ways and influenced their interpretations of their persistence towards their goals. When describing their experiences in undergraduate science learning environments, Jamie and 
Judy both described tensions related to their persistence due to conflicts between structures such as program, course, and schedule expectations and their gender and class: differing experiences in lecture and laboratory components, managing time, and weighing academic/career goals and personal priorities. Though these two women described the same persistence-related tensions in relation to these structures, their interpretations of their persistence (in responding to the cultural narrative of school as a competition) were individually shaped by their assent or rejection of either the school or home culture.

\title{
School as a Competition
}

Both Judy and Jamie began their college educations with a desire to be in the medical sciences. They both noted ways in which science professors fostered a competitive atmosphere at SU. However, they spent more time discussing how this atmosphere influenced their interactions with their peers-students, regardless of gender, finding ways to out-compete each other and to make other students feel badly about their position within the competition.

Judy attributed the competition to earn a spot in medical school as a major influence on the learning environment in her undergraduate science courses. This competition resulted in students constantly wanting to know how their grades compared to the grades of their peers. One of Judy's professors readily gave access to grades (though anonymously) for the class. Judy did not place blame with this instructor for the resulting competitive atmosphere. Instead she focused on the other students for making her feel like an academic non-competitor.

\begin{abstract}
Students are always comparing each other, like comparing our grades, because we're basically in competition with each other 'cause they know that we're all going to apply to medical school about the same time and they're like, 'Well you're never going to get in cause you don't get as good a grades as I do.' So although they won't say that to your face, but they're always like: 'Yeah, but you only got a B, right?' or, 'But you only got a C in that class, right?' And it's almost like, why don't you just say, 'I did better than you, you're not going to get in'? So it's just stressful. (Judy, I-1)
\end{abstract}

While Judy acknowledged the influence of the collective goals of the students to enter into competitive career fields on the learning environment, she acknowledged that the act of giving science majors access to each other's grades increased the competitive atmosphere in the classroom and provided support for the school as a competition narrative.

Jamie also thought instructors played a role in creating a competitive atmosphere. Jamie took a biology course in which students were asked to take group examinations as a way to encourage more engagement with the course material. In this course, assessment of group members was a part of the grading structure. Jamie noted that this situation resulted in students giving high grades to each other at the mid-point and then awarding each other low grades for the final assessment in order to come out on top.

When it comes down to the end of it, every person is like this because they would rather throw the other person under the bus in case they're going to be thrown under the bus. (Jamie, I-2)

After this course, Jamie avoided all classes, regardless of her interest level, that were structured in that way because she did not like the behind-your-back competitive behavior that it incited in her peers. Therefore, an instructor's effort to increase student engagement through social learning ended up making Jamie feel more frustrated than included. 


\section{Tensions}

Both Jamie and Judy struggled to persist in a competitive atmosphere given the tensions they described between structures related to program, course, and schedule expectations and their gender and class. The major persistence-related tensions described by Judy and Jamie included: (1) differing experiences in lecture and lab, (2) managing time for work, studying, and family, and (3) weighing academic/career and personal priorities. For Judy and Jamie, the ways in which they respond to these tensions comes through in their interpretations of their persistence in which they show alliance, or affinity, with either the academic culture or home culture.

Experiences in Lecture and Lab. Judy and Jamie's evaluations of their science courses were different depending on whether they were discussing the lecture or laboratory component of the course. They struggled to keep up with the amount of lecture material to remain competitive, but they enjoyed and felt successful in their laboratory classes. Judy discussed how the school as a competition narrative was a comfort to her peers most of the time because she did not have grades as high as they did in the upper level science courses in her major. In the laboratory component of upper level science courses, however, a student's ability to be a competitive threat shifted from grades to the performance of skills.

I've always loved lab and probably my favorite one, I've had two at [SU], I've had the microbiology lab and I've had basic lab skills. I have to say that the microbiology lab was the best, it was awesome, just because like a lot of it was hands on work, like probably 80 percent of it was hands on work, and I was always the best one at it. (Judy, I-2)

Jamie also enjoyed her course lab components more than the lectures, and like Judy, felt more successful in them.

As the technical part I understood that a lot and I'm really good at that, you know, being really steady, accurately measuring, contamination, stuff like that. Streaking. I can do that stuff really well. (Jamie, I-2)

Judy noted that her relative success in performing these skills in labs compared to her peers resulted in them treating her as if her lecture grades were the true measure of her science ability. Judy described it as a positioning of her as the "stupid" one, as a non-competitor:

They don't understand why I'm so good in lab ... I mean they usually do the experiments and they come out wrong, or they do them sloppy, or they're contaminated, or they can't remember how to do the steps, or they're so nervous that they mess something up, or they're just not good at it. But for me, it's fast, I just do it and I'm done. (Judy, I-2)

Judy felt positioned as a non-competitor because, despite her feelings of success and the laboratory instructor's acknowledgment and recognition of her lab abilities, her peers would not accept her help in lab. Judy explained their actions by saying that labeling her as stupid and positioning her as a non-competitor made them feel better about themselves and that was why they did not want to acknowledge her success in lab settings.

Jamie felt that practical skills in lab were important, though often overlooked as a priority. She thought that the practical skills developed in lab classes were just as important for success in a science career.

I mean you may be able to pass the genetics test, but then not really know how to draw something up in a syringe or in a pipette properly. It was halfway through the semester and 
there were people in our class that we found out were not using the pipettes properly. So I mean it's a good time to just learn those things that are really basic but necessary if you're going to do anything practical wise in science. (Jamie, I-2)

Jamie felt that the more abstract science knowledge in her lecture classes was not the only valuable learning focus in science and complained about working with partners with less practical know-how. In describing her experiences, Jamie positioned herself as superior to them in common sense and lab techniques.

I think I would have liked [lab] more if it hadn't been in partners cause ... even my lab write-ups I had to deal with another person and I have extremely aseptic technique and I would have to be like, 'You can't blow the bubble out of the test tube. You are blowing your DNA in there and this is a DNA sample. What is wrong with you?' I mean I thought that I was going to seriously strangle that person ... how is this experiment going to work if you can't even understand that there are germs in your mouth? (Jamie, I-2)

Jamie could not understand how a person doing better than her in the lecture component could have no common sense in the laboratory component.

Jamie's evaluation of the importance of practical lab skills, like Judy's evaluation, are not only related to her feelings of success in lab, but also to the connection of the skills to jobs that they are interested in seeking after graduation.

Lectures for me are hard, they're difficult, but whether it's in the garden or in a lab or you know outside doing whatever, all you have to do is explain it to me one time and I got it. As long as it's hands on. (Judy, I-3)

Both Jamie and Judy understood that the demands of being in the medical field were not just about your ability to memorize abstract information and perform well on written tests, but to be able to technically execute physical procedures. Their success in the laboratory components of science courses helped them to feel more competitive, and more persistent towards their sciencerelated career goals, despite the fact that a larger proportion of their grades in these courses came from lecture components.

Managing Time. In a competitive learning environment, Judy and Jamie struggled with upper-level science course loads. Managing time was a constant balancing act as they struggled with finding time to work, studying course material, and managing personal relationships.

As a full-time student while working two part-time jobs, Judy struggled with going to classes and labs during the day and working in the evening.

Usually I can't work unless it's like second shift and as you know second shift usually goes to like 10 or 11 o'clock at night which is really hard, especially if you're going to school and you have to work and you have no time to study. (Judy, I-2)

Though both Jamie and Judy knew their working hours changed their study habits, they did not have the option to be unemployed, as both were supporting themselves through school.

While taking a full-time load as a biological sciences major, Jamie also worked full-time. She would work the night shift so that she could attend her classes and labs during the hours these courses were typically offered ( $8 \mathrm{am}-4 \mathrm{pm})$. Though this flexibility in her working hours helped her to maintain full-time student status, she knew she was missing out on opportunities to participate in study groups with fellow classmates. 
I definitely know that they get together and study and I'm at work. And then I can come meet them after work, but by that time they've already studied for three or four hours and they don't want to study. So I end up studying by myself. (Jamie, I-2)

As a result of having a job, Jamie knew she could not participate in the social learning that her classmates were involved in outside of lecture.

While Judy and Jamie knew they needed to find time to study outside of work and classes, both specifically mentioned their difficulty with the amount of material they were expected to cover. The struggles they noted pertained to gender and class related constraints. Judy lamented that she had different constraints on her time to study than her peers because she had to maintain a home for herself.

Like a lot of them still live with their parents or their parents help them out a lot, so they don't have to worry about the extra stresses of life and I do. So it's like I don't have enough time, I don't have the time that they have, the flexibility that they have. Like I don't go in my room and study while my mom cleans my room and washes my clothes and pays my cell phone bill and makes dinner. Like I don't have that, so I think it makes it a lot harder on me than some of the others. (Judy, I-2)

Judy felt that her need to support herself through school was an academic disadvantage in that it not only constrained her time to study, but the additional burden of not having someone to take care of her domestic needs took away time that her peers had and were using to study.

While Judy focused on the burden of her home situation as a major time constraint, Jamie focused on the sacrifices she made in managing her time to remain successful and competitive.

I didn't get to go home for Easter where I'd planned on [being] . . . I was just like, there's no way, and I ended up studying all weekend long and not getting to go see my family and doing anything. But I did really well on the test but without doing that I wouldn't. It's just a lot more information that they pack into it and they'll expect you to know all of it. So it may not be that [science] is any harder, it's just the expectations of what you ought to know is really high. (Jamie, I-2)

Though she valued time with her family, especially at the holidays, Jamie felt that her sacrificing time with them was what she had to do in order to be successful.

Interestingly, while both Jamie and Judy talked about the significant expectations for science majors for out-of-class studying time, neither one of them mentioned specific courses or instructors. They talked about the significant out-of-class time commitments for learning lecture material in science courses in general as if was a matter-of-fact consequence of majoring in science. Additionally, neither one mentioned difficulty in keeping up with out-of-class work from the laboratory component of their courses. The tension of managing time to work, study course material, and maintain personal relationships is a result of the conflict that Judy and Jamie felt between the structures of undergraduate science learning environments and their gender- and class-related constraints.

Longer Period for Finishing Education. Both Jamie and Judy felt that their families were emotionally supportive of their decisions to attend college, even if they could not be financially supportive. However, they still felt tensions between their own academic goals and the expectations their families had for their personal lives. For Jamie, this tension came up when responding to a question about how her family felt about her attending college. Jamie admitted 
that while her mother did support her, she did not really understand why Jamie was going to the trouble to get a college degree:

She just wishes I would just hurry up and get married so that I would be someone else's problem because until I'm married she feels that I'm still like a child. But once I'm married then she's very much, like once my sister and my brother got married she doesn't call. Like you have your own life, you have your own family, then she stops kind of making sure you paid your tag, you know those kind of things, you know she'll leave you alone. But I think they do think that it's like a burden that I've put on myself for no reason. (Jamie, I-1)

Jamie recognized that her mother felt that she had misplaced her priorities on school instead of on family-related goals, like being a wife. She admitted that her academic goals were not valued in the same way by her parents, and that particularly her mother did not understand why she was delaying her progression towards family goals by remaining single.

Jamie's explanation of her choice to remain single was because she felt as if she could not remain an academic competitor while having a boyfriend.

It just really took me breaking up with my boyfriend ... my grades were suffering, and as much as it sucks, I mean, that's something that you have to give up, it's a sacrifice ... which really sucks especially for [him] because he's like, 'It's awful to know that the person I care about the most cannot succeed with me around.' And I'm like, 'It's not you, it's the time.' I work full-time and I'm in school full-time and it takes every second of my day to do this, so it's a sacrifice. You have to be ready to sacrifice a lot of things. Time is the most valuable thing. (Jamie, I-3)

Jamie's desire to persist as a science major at SU was strong enough that she was willing to sacrifice not only time spent with her family, but also goals that were important to her family for her personal life. She assented to the expectations of undergraduate science degree programs over the expectations of her home culture. Jamie felt confident in her persistence in her major, was looking forward to her graduation after one more semester of classes, and was already starting to apply for medical programs.

Judy, however, was struggling to feel persistent in such a competitive learning environment. When Judy discussed how she dealt with the competitive atmosphere, she tried to remember advice that her step-grandmother gave her:

She knows all about my family and when I get down, she tells me, 'Look at your family, just look at your family'... I mean they're all construction workers and factory workers and drive trucks and I mean they didn't get any type of education. So I guess if you compare me to that, it's great. But I don't compare myself to that because we have different goals in life. I compare myself to the people that have the same goals as I do, and when I do that, I'm on the lower end of the scale, 'cause I mean, those are the people I got to go up against in life and that sucks. (Judy, I-2)

Judy's step-grandmother encouraged her to use her family as a reference for comparison in order to feel good about the progress she has made towards her academic goals. Judy, however, did not want to use her family members as a reference. Judy recognized that she was not competing with her family members in school or in the job market because of their lack of education. Judy felt like she was competing to find her place in the world, competing to persist in reaching her goal of becoming a doctor, but also in moving class positions. She acknowledged that she was starting out in the competition "on the lower end of the scale" because her family background was in a lower 
class position than that of her peers. Judy emphasized that her feelings about her persistence towards her goals were in relation to those she was comparing herself against. She knew that because she held similar ambitions to her classmates, her evaluation of herself as an academic competitor was in reference to them.

A major part of Judy's feelings of lack of persistence was related to her attempts to balance the personal goals she shared with her home community and her academic goals. Judy wanted to be a doctor and a mother, yet she felt as if these two goals were valued differently amongst her peers from college and her high school friends. Judy's vacillation between these two goals-in terms of career ambitions (college peers) and motherhood (high school friends)—-mirrored the tension she felt between two different lifestyles. Judy discussed her personal and academic goals in relation to those she perceived her high school friends to hold:

\begin{abstract}
Would I rather live almost paycheck to paycheck and have a house, a home, and a husband and family? Or would I rather wait on that and live a little bit better than paycheck to paycheck and do it ten years after everybody else that I know? 'Cause I mean I'm 25, and every single one of my friends have kids, every single one of my friends have a house and a husband $\ldots$ and it kind of makes me feel like I'm behind. (Judy, I-2)
\end{abstract}

Judy referred to cultural priorities related to her gender and her class that she shared with her high school friends - the importance of young motherhood. Judy alluded to the idea that being 25 years old and not yet having children was beginning to push the boundary of how long she was willing to delay starting a family. She questioned her comfort in putting off this personal goal in order to continue to prioritize her academic goals. Judy felt that not only her social class position but also her gender made weighing the importance of her academic and personal goals more complex. Her recognition that in order to raise her social class position, she may have to delay her personal goals put Judy into a situation where she questioned both her personal and academic goals. Judy recognized the class- and gender-related constraints and their influence on her persistence towards her academic goals.

One of the reasons Judy felt conflicted between academic and personal goals was in the length of time necessary to reach her STEM career goals.

I'm looking at my major and I'm seeing, you know, am I ever going to get done? Am I ever going to pass these classes? Am I ever going to actually graduate? And when I actually graduate, how old am I going to be? ... So it's really difficult cause I feel like I'm missing out on a lot ... being a mother and having a family is something that's really important to $m e$, and at my age, I'm 25 , and if I just keep waiting and keep waiting, the harder it is going to be for me. (Judy, I-3)

Like Judy, Jamie's friends from high school did not share her academic ambitions. Unlike Judy, however, Jamie talked about how she felt different from her high school friends now that she was a college student and close to graduation. She felt as if her friends from home were no longer able to relate to her.

... [my friends] weren't even going to high school. They had babies and were doing other things, so it it's not like, I mean I could talk to them, but I don't think they could relate. And then it also, if you are talking about how your big experience is at school, that causes a conflict too because they're not doing those things. Are you looking down on them? Are you judging them? Are you rubbing it in their face that you think you're better? It's a big, you open up a can of worms with that. (Jamie, I-3) 
Jamie explained the consequences of trying to remain friends with people from home and using those friends as a social support. She felt she could not talk about her experiences at college with her high school friends because they would feel positioned as inferior when she would talk about her college experiences. Jamie listed a number of ways her high school friends reacted to her talking about her experiences, all of which involved possibly negative evaluations of people who do not attend college.

Jamie felt distanced from her high school friends due to their reactions to her gaining different life experiences by nature of moving away from home and attending college. Jamie felt as if these reactions contributed to her losing their friendships over time. She no longer considered herself as having close relationships with her high school friends:

Yeah, I don't know any of them ... unless I was going to stay there and live the same life that they do, yeah I mean it had to be that way. (Jamie, I-3).

Jamie felt as if her life experiences in college changed the nature of her friendships because she no longer felt as if she held things in common with her high school friends. Her choice to attend college caused her to start a new life and gain new life experiences-experiences to which her high school friends could not relate. This divergence in their life paths, Jamie believed, caused both herself and her friends to feel positioned as different, and, therefore, that this distancing from her high school friends may be a consequence of her choice to pursue social mobility as well as her choice to attend college.

Jamie said she initially mourned the loss of her high school friends, even though she came to see this loss as inevitable:

Sacrificed or let go? Which is it? Because am I really sacrificing that much by not having a child and not being able to send it to college? ... Like when I think of sacrificing, I think of like connotations of you're giving up something that is worthwhile. Was I giving up something that was worthwhile really? (Jamie, I-3)

Figuring out how to explain your experiences and the experiences of others has consequences for how you interpret the position of others in society, which includes people such as friends and family. Though Jamie lost her state-sponsored scholarship and had to withdraw from school, she re-enrolled and worked full-time to pay her way through school. Her determination to graduate and get a science degree was evident in the gender- and class-related decisions she described making to keep her education a priority in her life: working full-time to pay for school, ending romantic relationships in order to maintain a higher grade point average, and skipping family holiday celebrations in order to study. Jamie felt that her academic journey as an undergraduate science major was a success as she looked forward to graduation. She was not worried about how her life was moving her away from her cultural background.

$\mathrm{R}:$ What do you think has helped you persist as a first generation student?

J: I guess my desire to succeed. A lot of it has to do with the fact that I want to fit in with the other side and I had to choose, am I going to be here forever, or if I want to fit in with this other side that has things and does normal things. I mean, that's how I feel about college people and people who aren't. Like people who have like college degrees and professions and who aren't blue-collared construction workers and homemakers and things like that. I do. It's like a whole other side. (Jamie, I-3)

Jamie developed a negative evaluation of her friends' social class position. Jamie's friends did not seek social mobility, so when she thought of whether or not she had sacrificed their 
in order to persist, she admitted that she simply "let go" of their friendship, because their friendships might be worth less, just like the life they were living - that she was trying to move away from-might be worth less. Her negative evaluation of other people from home who had not accomplished what she had aided her in seeing the loss of her high school friendships as a reasonable cost to her social mobility.

Despite Jamie and Judy both recognizing the conflict between the gender- and class-related values of their cultural backgrounds and expectations of their undergraduate science programs, their interpretations of their persistence within these programs is related to their affinity with either their school or home culture. Their choice of affinity to their school or home culture, therefore, reflects their constrained agency within the structure of their undergraduate science environment.

\section{Discussion and Implications}

In this article, we analyzed how two female first-generation college students evaluated their persistence within their undergraduate science programs and how their evaluations of their persistence were in response to tensions they described between the expectations of their undergraduate science programs and gender- and class-related values of their cultural background. Judy and Jamie each referred to the cultural narrative school as a competition as an explanation for who persists in undergraduate science, that is, who is and is not an academic competitor. They described the same class- and gender-related tensions they experienced as they tried to position themselves as academic competitors in their undergraduate science programs: (1) differing experiences in lecture and laboratory components, (2) managing time for work, studying, and family, and (3) weighing their personal (family) priorities against the longer time it would take them to reach their science-related career goals. These persistence-related tensions position female lower-income students as "academic non-competitors" unless they are willing to divorce themselves of priorities related to their cultural background such as the importance of physical skills and personal relationships.

\section{Tensions as Classed and Gendered}

The tensions felt by Judy and Jamie related to their persistence in science and values associated with their cultural backgrounds are significant. These women, in describing the circumstances influencing their persistence towards their goals, explain how being a female, lowincome student in an undergraduate science program positions them at a disadvantage in relation to their peers. Jamie and Judy lamented that there was less value for the physical, tactile skills they brought to the classroom (lecture prioritized over laboratory) and, in order to remain competitive, that they spent an inordinate amount of time learning lecture material individually and outside of class hours.

Lareau's $(2002,2003)$ work provides a lens through which to view undergraduate sciencein placing more emphasis on lecture components over lab components—as supporting values of middle class students. In her research related to family life and childhood experiences, Lareau $(1987,2002,2003)$ argued that differing cultural practices of Black and White middle and lowerclass families influence the development of children's practices, and thus their success in school. Middle-class family culture emphasizes the development of reasoning and communication skills as a form of discipline, as well as the cultivation of individuality, which affords their children with distinct advantages when dealing with mostly middle-class adults in institutions such as schools (Lareau, 2002, 2003). While children from lower-class families developed other equally valuable practices, such as resourcefulness, deep kinship ties, and feelings of loyalty, these traits were less advantageous in their achievement in a school context permeated with middle class values (Lareau, 2002). This difference in valuation and development of knowledge (abstract vs. practical) 
in Lareau's (2002) work is associated with different social class positions (middle vs. lower). The split in traditional undergraduate science courses between lecture and laboratory components results in a separation between abstract and practical knowledge. This research helps to explain why Jamie and Judy, having grown up in lower-class families, would feel more comfortable in the laboratory components of a traditional undergraduate science course where practical knowledge is more useful.

In addition, Judy and Jamie's descriptions of their tensions in relation to the school as a competition narrative are consistent with the characteristics of a gender-neutral environment as described by Eisenhart and Finkel (1998). Judy and Jamie felt that in order to maintain a competitive science student identity they needed to align themselves with values that are those of a prototypical white male: (1) your job as a full-time student comes first, (2) your primary goal is your career, (3) you should not sacrifice student responsibilities for domestic or family responsibilities, and (4) there are expectations to work (study) more than full-time. In addition, Eisenhart and Finkel (1998) argued that the behaviors described above are associated with a man who has a full-time wife at home to manage his personal life. For lower-income women like Judy and Jamie, they could not sacrifice their roles as full-time life managers for themselves. They held jobs so that they could afford to enroll in school. They could not afford to pay for school without a job and they could not afford to pay someone else to manage their domestic lives for them. Therefore, not only do Judy and Jamie's experiences support the gendered expectations needed to succeed in a science environment, these are also class-based expectations. If you are a low-income student who needs to work while in school, managing time to prioritize your full-time education is a challenge.

Jamie and Judy's recognition of the tension between their lives as workers, as science majors, and as members of their families is supported by Lareau's (Lareau, 1987, 2002) findings that kinship ties are prioritized differently by class in relation to education. Lareau's (2002) description of middle class families privileging individuality while lower class families privilege kinship ties also provides a lens to make sense of Jamie and Judy's difficulties in managing time to work, study, and maintain family relationships. Having a job outside of being a full-time student meant not only less time to study, but also less time to engage outside of class with other science students in social learning. In contrast to the female, first-generation college students in Packard et al.'s (2011) study, this research supports the importance of personal relationships in Jamie and Judy's families was in conflict with undergraduate science culture. Judy and Jamie described their consideration of their personal (family) priorities alongside the amount of time it would take them to reach their science-related career goals. They recognized that this significant time commitment had greater implications for them maintaining family relationships as well as starting a family. As women, Jamie and Judy may have different demands as family members than male students, such as expectations to marry and have children at relatively young ages, which pursuing science careers is delaying. Rather than reinforcing a stereotype of female students as more caring and desirous of personal connections, this research presents the gendered and classed tensions described by Jamie and Judy as the result of a conflict of cultures-one focusing on the abstract and the individual and one focused on the physical world and human connection.

\section{Conflict of Cultures}

If science departments as "institutions reflect classed, racial, and gendered practices" (Weis, 1995, p. 164) as discussed by scholars such as Risman (2004), Collins (2000), Harding (2008), and Eisenhart and Finkel (1998), then how do White, lower-income, female students like Jamie and Judy position themselves in relation to it? While Jamie and Judy both described the same gendered and classed tensions in relation to their persistence in science, they responded to 
these tensions in different ways. Judy and Jamie positioned themselves vis-à-vis their peers differently. Jamie positioned herself as an academic competitor and made great sacrifices to keep herself in that position. She allied herself with the White, Western, rational epistemology of science that success lies in the individual effort of the person who focuses on their future self (Perry, 2001). Jamie felt that sacrificing her social life, time spent with her family, and study time with peers due to balancing full-time work and full-time enrollment was worth the effort if it meant social mobility in the form of her college degree and a science-related job. Jamie did not seem concerned, or even surprised that her sacrifices were resulting in her becoming more distant from her home community.

In contrast, Judy felt torn between her academic and personal priorities, which mirrored two different cultural worlds. Judy did not feel able to fully focus on her future individual self at the expense of her past self as a part of her home community. Her positioning of herself as an academic non-competitor was related to how she felt at a disadvantage due to her social class in comparison with her college peers. Judy lamented the sacrifices of balancing work and studying while delaying a family to focus on academic goals rather than personal goals. Judy wanted the social mobility promised by a college degree in science because she believed it would make her life more stable, but she valued the lifestyle and the importance of family shared by her lower class friends. Judy did not waiver in her interest in or personal affiliation with science. However, Judy's inability or unwillingness to disregard the lifestyle of her class background resulted in her not being able to fully ally herself with the cultural values of undergraduate science-a focus on a future individual self-and she struggled to feel persistent towards her science-related career goals.

\section{Consequences of Cultural Alliance}

When school culture comes into conflict with the cultural background of lower-income students like Judy and Jamie, there are consequences for their personal feelings of persistence and their evaluation of others. This is a significant finding because it shows that one of the cultural messages of undergraduate science described by Johnson (2007) - "the construction of science as a gender-, ethnicity-, and race-neutral meritocracy" (p. 810) - is detrimental not only to racialminority, female students, but also to White, low-income females. The gender and class-related tensions of managing time for work, school, and domestic responsibilities resulted in Judy positioning herself as an academic non-competitor. In contrast, Jamie chose to position herself as an academic competitor, sacrificing personal goals supported by her family, in order to maintain her feelings of persistence in her undergraduate science program. In focusing on her future, individual self, Jamie realized that her dedication to her academic goals resulted in her feeling distanced from her home community. She did not lament this distance because she valued this connection less than she valued the possibilities of social mobility. Despite their agency in choosing which culture to ally with (home or school), for Jamie and Judy, either choice resulted in negative consequences for themselves (Judy) or their perspectives of others from their home community (Judy and Jamie).

Thus, these findings support the calls from other researchers to encourage scientists in recognizing that "science has a culture, and that certain types of students may find it challenging to understand and navigate this culture" (Johnson, 2007, p. 819). Jamie and Judy's narratives shed some light onto explanations of why the socioeconomic background of students has a negative influence on their persistence in STEM fields, even as they retain interest in the field (Hanson, 1996; Packard \& Babineau, 2009; Packard et al., 2011). Judy and Jamie's descriptions of the tension between the abstract knowledge and individual-focused science culture and their practical knowledge and relationship-focused home culture aids in explaining why female, 
low-income students may find undergraduate science learning environments unwelcoming (Packard et al., 2011).

\section{Recommendations}

Despite this tension in cultures experienced by Jamie and Judy, how can we help students like them to persist in their science-related career goals? Scientists and other higher education faculty in positions to support students persisting towards their science-related career goals should be aware of the possibilities for conflicts in cultural values that such students may be navigating. While students like Jamie will show little signs of struggle over such conflicts, students need added supports to help them make sense of a stage of significant change in their lives. In our final conversation during data collection, Judy was quite interested in how many other students had been interviewed who shared her circumstances and how much she wanted to find others like her so that she could have a family at school to be a part of. Efforts to bring first-generation or lowincome students together in student organizations, whether at the department or institutional level (Davis, 2010), are an important step towards recognizing that this is a population of students in science who would benefit from social interaction and engagement with peers outside of formal classes. Unlike their membership in gender or racial/ethnic groups, their positions as firstgeneration or low-income students is largely an invisible identity that makes it harder for these students to find each other without some assistance. Finding students with whom they can share stories of persistence and struggle could aid them in developing personal relationships that can fill a cultural kinship need when their academic studies keep them away from home and family.

Arguably a more significant contribution to their academic persistence is the structural reformation of undergraduate science programs (Fox et al., 2011). Most notably, there has been a growing concern from instructors concerning low attendance rates and achievement in undergraduate science courses, resulting in new initiatives to change the curriculum and the structure of such courses. Reformed courses in some Biology and Physics departments include teaching strategies focused on more active learning and peer teaching within lectures (Crouch \& Mazur, 2001), integrating lecture with hands-on lab activities (Burrowes \& Nazario, 2008), and integrating mini-lectures with student working groups for problem solving and visualization of micro-phenomena (Dori \& Belcher, 2005). These reforms increase opportunities for student social learning as well as opportunities for physical manipulation of materials while thinking about the abstract concepts they are learning. The social learning strategies and integration of physical and abstract learning have led to significant achievement gains in courses (Burrowes \& Nazario, 2008; Crouch \& Mazur, 2001; Dori \& Belcher, 2005) and are critical structural reforms to classroom climate (Fox et al., 2011) to support the needs of students such as Jamie and Judy. For students whose home culture prioritizes the development of practical knowledge and relationships, science courses with more opportunities for social learning that also integrate physical manipulation with abstract knowledge can become more culturally familiar. It is important for instructors to promote student collaboration for the construction of knowledge within these social learning environments in order to aim for a more accessible undergraduate science learning context for all students (Carlone et al., 2011). These changes in traditional lecture and laboratory science teaching provide models for other universities to follow as they support greater learning for all students in undergraduate science courses.

\section{References}

Aronowitz, S. (1992). The politics of identity: Class, culture, social movements. New York: Routledge.

Bem, S. L. (1993). The lenses of gender: Transforming the debate on sexual identity. New Haven, CT: Yale University Press. 
Bettie, J. (1995). Class dismissed? Roseanne and the changing face of working-class iconography. Social Text 45, 14(4), 125-149.

Bettie, J. (2003). Women without class: Girls, race, and identity. Berkeley: University of California Press.

Billson, J. M., \& Terry, M. B. (1982). In search of the silken purse: Factors in attrition among firstgeneration students. College and University, 58(1), 57-75.

Brickhouse, N. W., Lowery, P., \& Schultz, K. (2000). What kind of girl does science? The construction of school science identities. Journal of Research in Science Teaching, 37(5), 441-458.

Brandt, C. (2008). Scientific discourse in the academy: A case study of an American Indian Undergraduate. Science Education, 92, 825-847.

Burrowes, P., \& Nazario, G. (2008). Promoting student learning through the integration of lab and lecture. Journal of College Science Teaching, 37(4), 18-23.

Calabrese Barton, A., Kang, H., Tan, E., O’Neill, T. B., Bautista-Guerra, J., \& Brecklin, C. (2013). Crafting a future in science: Tracing middle school girls' identity work over time and space. American Educational Research Journal, 50, 37-75.

Calabrese Barton, A., \& Yang, K. (2000). The culture of power and science education: Learning from Miguel. Journal of Research in Science Teaching, 37(8), 871-889.

Carlone, H. B., Haun-Frank, J., \& Webb, A. (2011). Assessing equity beyond knowledge- and skillsbased outcomes: A comparative ethnography of two fourth-grade reform-based science classrooms. Journal of Research in Science Teaching, 48(5), 459-485.

Carlone, H. B., \& Johnson, A. (2007). Understanding the science experiences of successful women of color: Science identity as an analytic lens. Journal of Research in Science Teaching, 44(8), 1187-1218.

Charmaz, K. (2006). Constructing grounded theory: A practical guide through qualitative analysis. Los Angeles: Sage.

Choy, S. P. (2001). Students whose parents did not go to college: Postsecondary access, persistence, and attainment (No. 2001-126). Washington, D.C.: U.S. Department of Education, National Center for Education Statistics.

Collins, P. H. (1999). Moving beyond gender: Intersectionality and scientific knowledge. In M. M. Ferree, J. Lorber, \& B. B. Hess (Eds.), Revisioning gender (pp. 261-284). Thousand Oaks, CA: Sage.

Collins, P. H. (2000). Black feminist thought: Knowledge, consciousness, and the politics of empowerment (ed). New York: Routledge.

Crotty, M. (1998). The foundations of social research: Meaning and perspective in the research process. London: Sage.

Crouch, C. H., \& Mazur, E. (2001). Peer instruction: Ten years of experience and results. American Journal of Physics, 69(9), 970-977.

Dahlberg, K. (2006). The essence of essences-The search for meaning structures in phenomenological analysis of lifeworld phenomena. International Journal of Qualitative Studies on Health and Well-being, 1, $11-19$.

Davis, J. (2010). The first-generation student experience: Implications for campus practice, and strategies for improving persistence and success. Sterling, VA: Stylus Publishing.

Dori, Y. J., \& Belcher, J. (2005). How does Technology-Enabled Active Learning affect undergraduate students' understanding of electromagnetism concepts? The Journal of the Learning Sciences, 14(2), 243-279.

Ecklund, E. H., Lincoln, A. E., \& Tansey, C. (2012). Gender segregation in elite academic science. Gender \& Society, 26(5), 693-717.

Eisenhart, M. A., \& Finkel, E. (1998). Women's science: Learning and succeeding from the margins. Chicago, IL: The University of Chicago Press.

Erwin, L., \& Maurutto, P. (1998). Beyond access: Considering gender deficits in science education. Gender and Education, 10(1), 51-69.

Fox, M. F., Sonnert, G., \& Nikiforova, I. (2011). Programs for undergraduate women in science and engineering: Issues, problems, and solutions. Gender \& Society, 25(5), 589-615. 
Freeman, M. (2007). Performing the event of understanding in hermeneutic conversations with narrative texts. Qualitative Inquiry, 13(7), 925-944.

Hanson, S. L. (1996). Lost talent: Women in the sciences. Philadelphia, PA: Temple University Press.

Harding, S. (Ed.). (1993). The "racial economy" of science: Toward a democratic future. Bloomington, IN: Indiana University Press.

Harding, S. (2008). Sciences from below: Feminisms, post-colonialities, and modernities. Durham, NC: Duke University Press.

Hartmann, D., Gerteis, J., \& Croll, P. R. (2009). An empirical assessment of White theory: Hidden from how many? Social Problems, 56(3), 403-424.

Holland, D. C., Lachicotte, W. J., Skinner, D., \& Cain, C. (1998). Identity and agency in cultural worlds. Cambridge, MA. Harvard University Press.

Holland, D., \& Leander, K. (2004). Ethnographic studies of positioning and subjectivity: An introduction. Ethos, 32(2), 127-139.

Hurtado, S., Eagan, M. K., Tran, M. C., Newman, C. B., Chang, M. J., \& Velasco, P. (2011). "We do science here": Underrepresented students' interactions with faculty in different college contexts. Journal of Social Issues, 67(3), 553-579.

Hurtado, S., Han, J. C., Sáenz, V. B., Espinosa, L. L., Cabrera, N. L., \& Cema, O. S. (2007). Predicting transition and adjustment to college: Biomedical and behavioral science aspirants' and minority students' first year of college. Research in Higher Education, 48(7), 841-887.

Johnson, A. (2007). Unintended consequences: How science professors discourage women of color. Science Education, 91, 805-821.

Johnson, A., Brown, J., Carlone, H., \& Cuevas, A. K. (2011). Authoring identity amidst the treacherous terrain of science: A multiracial feminist examination of the journeys of three women of color in science. Journal of Research in Science Teaching, 48(4), 339-366.

Lareau, A. (1987). Social class differences in family-school relationships: The importance of cultural capital. Sociology of Education, 60(2), 73-85.

Lareau, A. (2002). Invisible inequality: Social class and childrearing in Black families and White families. American Sociological Review, 67(5), 747-776.

Lareau, A. (2003). Unequal childhoods: Class, race, and family life. Berkeley: University of California Press.

Lave, J., \& Wenger, E. (1991). Situated learning: Legitimate peripheral participation. New York, NY: Cambridge University Press.

Levinson, B. A., \& Holland, D. (1996). The cultural production of the educated person: An introduction. In B. A. Levinson, D. E. Foley, \& D. C. Holland (Eds.), The cultural production of the educated person: Critical ethnographies of schooling and local practices (pp. 1-54). Albany, NY: State University of New York Press.

Lohfink, M. M., \& Paulsen, M. B. (2005). Comparing the determinants of persistence for first-generation and continuing-generation students. Journal of College Student Development, 46(4), 409-428.

London, H. B. (1992). Transformations: Cultural challenges faced by first-generation students. New Directions for Community Colleges, 80, 5-12.

Longino, H. E. (1990). Science as social knowledge: Values and objectivity in scientific inquiry. Princeton, NJ: Princeton University Press.

Lorber, J. (1994). Paradoxes of gender. New Haven, CT: Yale University.

Lorber, J. (2011). Strategies of feminist research in a globalized world. In E. N. Chow, M. T. Segal, \& L. Tan (Eds.), Analyzing gender, intersectionality, and multiple inequalities: Global, transnational, and local contexts (p. 35-49). Bingley, UK: Emerald Group Publishing Limited.

Merriam, S. B. (1998). Qualitative research and case study applications in education. San Francisco: Jossey-Bass Publishers.

National Science Board. (2003). The science and engineering workforce: Realizing America's potential (NSB 03-69). Arlington, VA: National Science Foundation. Retrieved from National Science Foundation website: https://www.nsf.gov/nsb/documents/2003/nsb0369/ 
National Science Foundation, Division of Science Resources Statistics. (2011). Women, Minorities, and Persons with Disabilities in Science and Engineering: 2011 (NSF 11-309). Arlington, VA: National Science Foundation. Retrieved from National Science Foundation website: http://www.nsf.gov/statistics/wmpd/

Nuñez, A., \& Cuccaro-Alamin, S. (1998). First-generation students: Undergraduates whose parents never enrolled in postsecondary education (No. 98-082). Washington, D.C.: U.S. Department of Education, National Center for Education Statistics.

Ong, M. (2005). Body projects of young women of color in physics: Intersections of gender, race, and science. Social Problems, 52(4), 593-617.

Orbe, M. P. (2004). Negotiating multiple identities within multiple frames: An analysis of firstgeneration college students. Communication Education, 53(2), 131-149.

Packard, B. W., \& Babineau, M. E. (2009). From drafter to engineer, doctor to nurse: An examination of career compromise as renegotiated by working-class adults over time. Journal of Career Development, 35, 207-227.

Packard, B. W., Gagnon, J. L., LaBelle, O., Jeffers, K., \& Lynn, E. (2011). Women's experiences in the STEM community college transfer pathway. Journal of Women and Minorities in Science and Engineering, 17(2), 129-147.

Patton, M. Q. (2002). Qualitative research and evaluation methods (3rd ed.). Thousand Oaks, CA: Sage Publications.

Perry, P. (2001). White means never having to say you're ethnic: White youth and the construction of "cultureless" identities. Journal of Contemporary Ethnography, 30(1), 56-91.

Polkinghorne, D. E. (1988). Narrative knowing and the human sciences. Albany, NY: State University of New York Press.

Polkinghorne, D. E. (1995). Narrative configuration in qualitative analysis. In R. Wisniewski \& J. A. Hatch (Eds.), Life history and narrative (pp. 5-23). Washington, D.C.: Falmer.

Rhoton, L. A. (2012). Distancing as a gendered barrier: Understanding women scientists' gender practices. Gender \& Society, 25(6), 696-716.

Richardson Bruna, K., \& Vann, R. (2007). On pigs and packers: Radically contextualizing a practice of science with Mexican immigrant students. Cultural Studies of Science Education, 2(1), 19-59.

Ricoeur, P. (1984). Time and narrative, Volume I (K. McLaughlin \& D. Pellauer, Trans.). Chicago, IL: The University of Chicago Press.

Ricoeur, P. (1992). Oneself as another (K. Blamey, Trans.). Chicago: The University of Chicago Press.

Risman, B. J. (1998). Gender vertigo. New Haven, CT: Yale University Press.

Risman, B. J. (2004). Gender as a social structure: Theory wrestling with activism. Gender and Society, 18(4), 429-450.

Schmidt, P. (2010). In push for diversity, colleges pay attention to socioeconomic class. Chronicle of Higher Education, 57(5), B5-B7.

Seidman, I. (2006). Interviewing as qualitative research: A guide for researchers in education and the social sciences. (3rd ed.). New York: Teachers College Press.

Seymour, E. (1995). The loss of women from science, mathematics, and engineering undergraduate majors: An explanatory account. Science Education, 79(4), 437-473.

Weis, L. (1990). Working class without work: High school students in a de-industrializing economy. New York: Routledge.

Weis, L. (1992). Discordant voices in the urban community college. New Directions for Community Colleges, 80, 13-28.

Weis, L. (1995). Qualitative research in sociology of education: Reflections on the 1970s and beyond. In W. T. Pink \& G. W. Noblit (Eds.), Continuity and contradiction: The futures of the sociology of education (pp. 157-173). Cresskill, NJ: Hampton Press, Inc.

Weis, L. (2004). Class reunion: The remaking of the American white working class. New York: Routledge.

Willis, P. (1977). Learning to labor: How working class kids get working class jobs. New York, NY: Columbia University Press.

Yin, R. K. (2009). Case study research: Design and methods. (4th ed). Thousand Oaks, CA: Sage. 